\title{
SIMPUL-SIMPUL PENDIDIKAN DALAM SURAH AL ANFÂL DAN AL TAUBAH
}

\author{
Noorazmah Hidayati \\ Dosen STAI RAKHA Amuntai/Mahasiswa Program Doktor \\ IAIN Antasari Banjarmasin
}

\begin{abstract}
Today, concept of jihad disposed wrong to be understood. Jihad mean as a war, even must destroyed some people and creatures with in the name of Islam. As a consequence Islam refer to a terorist religion. This opinion must be corrected, because Islam is "rahmatan lil 'alamiin". In fact, in independent time jihad should be manifested to protect equitable and moral of humanbeing. This article describes some essences of education of jibad in surah al Anfâl and al Taubah with the result that every action will valued as jihad and humanbeing values will protected.
\end{abstract}

Kata kunci: jïhad, simpul-simpul pendidikan dalam surah al Anfâl, dan simpul-simpul pendidikan dalam surah al Taubah.

\section{Pendahuluan}

Surah al Anfâl dan al Taubah berurutan tempatnya dalam urutan Mushaf Utsmani. Di samping itu, keduanya mengandung konten yang memiliki banyak kesamaan, yaitu berkenaan dengan jihad, dimana pada al Anfâl dideskripsikan keadaan Nabi pada masa awal perjuangan dan pertengahannya dan al Taubah menguraikan tentang penghujung atau akhir perjuangan Nabi. ${ }^{1}$ Selain itu, dalam kedua surah ini digambarkan konsolidasi umat dan bimbingan kepada kaum muslim menuju kehidupan baru secara kolektif. ${ }^{2}$ Terdapatnya keterkaitan tema pada dua surah ini kemudian dicoba untuk diambil tema utamanya yaitu perjuangan.

Istilah Qur'an untuk menunjukkan perjuangan adalah kata jihad. Hanya saja, istilah ini cenderung sering disalah arti dan dipersempit maknanya. ${ }^{3}$ Dalam konteks sekarang, pemahaman jihad cenderung telah menyimpang dari yang seharusnya, dimana jihad diartikan sebagai perang meskipun dengan cara membinasakan makhluk lain dengan mengatasnamakan agama yang ideologinya dianggap tidak sepaham dan sejalan dengannya. Akibatnya, pemahaman yang keliru tersebut berlanjut dimana Islam dianggap sebagai ajaran teroris. Hal ini tentu harus diluruskan, karena ajaran Islam tidaklah demikian.

Di masa Rasul, ketika kaum muslimin dijajah oleh kaum kafir Mekkah, kaum muslimin berjihad melalui perang sebagai manifestasi keimanan mereka yang tentu saja mengakibatkan hilangnya jiwa, harta benda, dan melahirkan kesedihan dan air mata. Sekarang, di masa kemerdekaan jihad harus membuahkan terpeliharanya jiwa dan terwujudnya kemanusiaan yang adil dan beradab.

\footnotetext{
${ }^{1}$ M. Quraish Shihab, Tafsir al Misbah: Pesan, Kesan, dan Keserasian al Qur'an, Volume 4, (Jakarta: Lentera Hati, 2010), h. 447 ${ }^{2}$ Djohan Effendi, Pesan-pesan al Qur'an, (Jakarta: PT Serambi Ilmu Semesta, 2012), h. 97

${ }^{3}$ M. Quraish Shihab, Wawasan al Qur'an: Tafsir Maudhu'i atas Pelbagai Persoalan Umat, (Bandung: Mizan, 1997), h. 501
} 
Melalui tulisan ini diharapkan gambaran surah dengan tema perjuangan dapat ditarik simpul-simpul pendidikannya sehingga setiap perbuatan akan bernilai jihad dan nilai-nilai kemanusiaan akan terpelihara.

\section{Simpul-Simpul Pendidikan dalam Surah al Anfâl}

\section{Sekilas tentang Surah al Anfâl}

Al Anfâl adalah surah ke-8, diturunkan di Madinah pada urutan ke-88, setelah al Baqarah dan sebelum Ali 'Imran. ${ }^{4}$ Surah ini adalah surah Madaniyah yang berjumlah 75 ayat, 1631 kalimat (kata), 5294 huruf..$^{5}$ Surah ini membicarakan hukum seperti jihad dan ghanimah (harta rampasan perang). ${ }^{6}$ Nama lain yang juga dikenal untuk surah ini adalah surah "Badar". Nama tersebut lahir, karena ayat-ayat ini menguraikan tentang peperangan Badar yang merupakan perang antara Rasulullah saw bersama kaum muslimin melawan kaum Musyrikinin Mekkah, di lembah yang bernama Badar. Ia juga dinamai surah jihad, karena banyak ayat-ayatnya berbicara tentang jihad. ${ }^{7}$

Surah al Anfâl turun setelah perang Badar. Arti Anfal itu sendiri adalah sama dengan ghanimah atau rampasan harta perang, karena secara historis bahwa perang Badar merupakan pertempuran kaum muslimin melawan kaum kuffar Quraisy yang jumlahnya jauh lebih besar dari kaum muslimin, dan pertempuran ini dipimpin langsung oleh baginda Rasulullah saw. Ternyata umat Islam mengalami kemenangan dan mendapatkan harta rampasan perang yang cukup banyak.

Riwayat lain menyebutkan bahwa surah al Anfâl turun pada waktu perang Badar Kubra pada bulan Ramadhan tahun ke-2 Hijriyah. Pendapat yang mengatakan bahwa surah ini diturunkan sesudah surah al Baqarah tidak menggambarkan hakikat yang final. Pasalnya surah al Baqarah tidak diturunkan sekaligus, di antara ayat-ayatnya ada yang turun pada masa permulaan Madinah dan ada pula turun pada masa-masa akhirnya. ${ }^{8}$

Terlepas dari perbedaan pendapat tentang kapan turunnya surah al Anfâl yang jelas surah ini berbicara tentang perang Badar dan pembagian harta rampasan perang (ghanimah/Anfal), dimana dalam surah ini terdapat simpul-simpul pendidikan yang dapat diambil. Adapaun simpul-simpul pendidikan yang dapat dipahami dari surah al Anfâl ini dapat diuraikan pada penjelasan di bawah berikut.

\section{Pendidikan Akidah atau Keimanan yang Murni}

Pada surah an Anfal: 2-4 berbunyi:
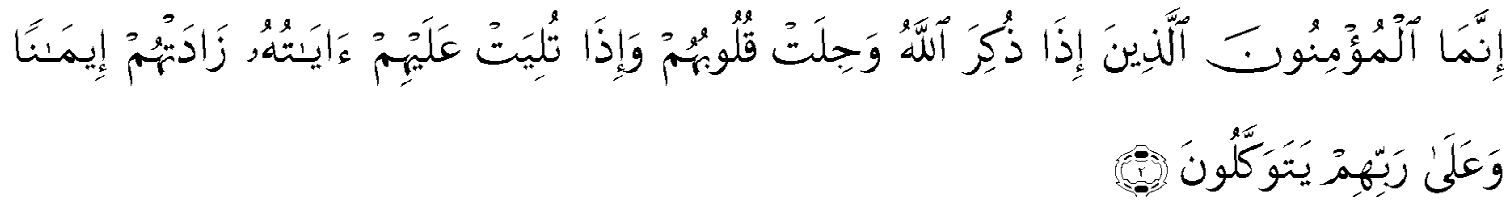

${ }^{4}$ Djohan Effendi, Pesan-pesan al Qur'an, (Jakarta: PT Serambi Ilmu Semesta, 2012), h. 97

${ }^{5}$ Maktabah Syamilah, (Tafsir Digital), Tabsir Ibnu Katsir, juz 9

${ }^{6}$ Wahbah Zuhaili, dkk, Buku Pintar al Qur'an Seven in One, (Jakarta: al Mahira, 2009), h. 178

${ }^{7}$ M. Quraisy Shihab, Tafsir al Misbah (Pesan, Kesan, dan Keserasian al Qur'an), Volume 4, (Jakarta: Lentera Hati, 2002), h. 446

${ }^{8}$ Sayyid Qutbh, Tafsir Fiøhilalil Qur'an (Di bawah Naungan al Qur'an) Jilid 5, alih bahasa: Sa'id Yasin dkk, (Jakarta: Gema Insani, 2003), h. 95 
Sesungguhnya orang-orang yang beriman ialah mereka yang bila disebut nama Allah gemetarlah hati mereka, dan apabila dibacakan ayat-ayatNya bertambahlah iman mereka (karenanya), dan Hanya kepada Tuhanlah mereka bertawakkal.

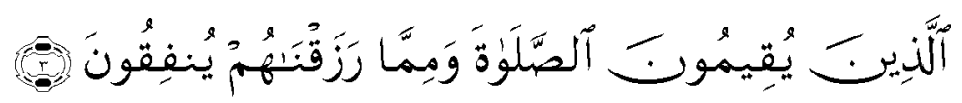

(yaitu) orang-orang yang mendirikan shalat dan yang menafkabkan sebagian dari rezki yang kami berikan kepada mereka.

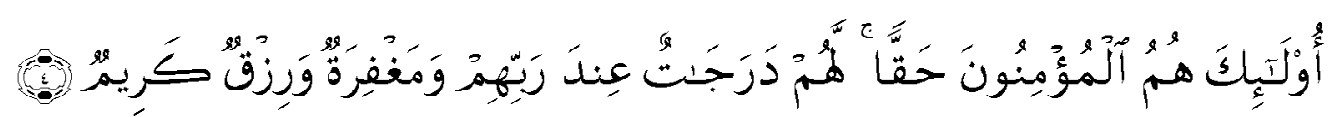

Itulah orang-orang yang beriman dengan sebenar-benarnya. mereka akan memperoleb beberapa derajat ketinggian di sisi Tuhannya dan ampunan serta rezki (nikmat) yang mulia.

Ayat pertama dari surah al Anfâl berisi tentang harta rampasan perang dibagi menurut ketentuan Allah dan rasul-Nya, selanjutnya diperintahkan bertakwa dan memperbaiki hubungan antarmuslim. Selanjutnya pada ayat kedua sampai dengan ayat keempat, Allah menyatakan ciri atau sifat orang yang beriman, yaitu apabila disebut nama Allah bergetarlah hatinya, bila dibacakan ayat-ayat-Nya bertambah kualitas imannya, selalu bertawakkal kepada Allah pada setiap urusan, melaksanakan shalat dan menafkahkan sebagian hartanya. Sifat-sifat di atas merupakan iman yang sebenarnya dimana bagi yang bersifat demikian maka ia berhak mendapatkan derajat yang tinggi di sisi Allah, ampunan, dan rezeki yang mulia. ${ }^{9}$

Menurut Ibnu Abbas dalam Tafsir Ibnu katsir menyebutkan:

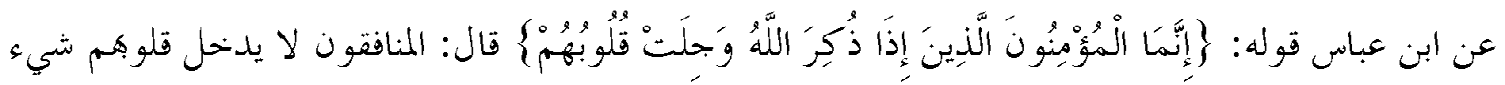

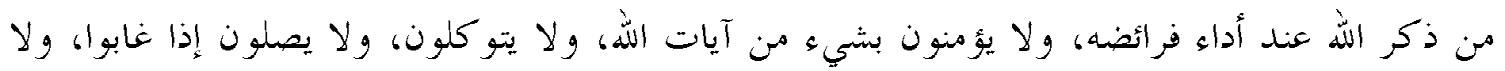

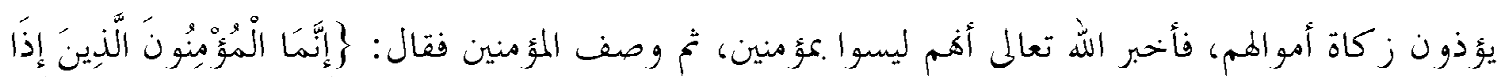

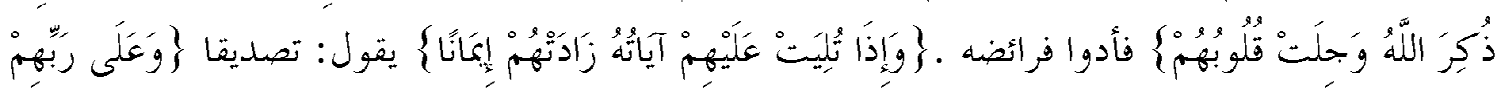

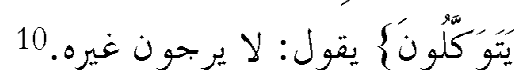

Dari Ibnu Abbas r.a. Firman Allah SWT (Sesungguhnya orang-orang yang beriman adalah mereka yang apabila disebut nama Allah bergetar hati mereka) dikatakannya: orang-orang munafik tidak mengingat Allah ke dalam hati mereka sekalipun mereka sedang menunaikan kewajiban kepada Allah, mereka sedikitpun tidak beriman kepada ayat-ayat Allah, tidak bertawakkal kepada Allah, tidak shalat manakala terbenam, dan tidak menunaikan zakat harta mereka, lalu Allah swt memberitahukan bahwasanya mereka bukanlah orang-orang mukmin, kemudian Allah swt menetapkan sifat atau karakteristik orang beriman, dalam firman-Nya: (Sesungguhnya orang-orang yang beriman adalah mereka yang apabila disebut nama Allah bergetar hati mereka), mereka menunaikan berbagai kewajiban, (dan apabila diperdengarkan

${ }^{9}$ Ali Abd al Him mahmud, al Tarbiyah al Islamiyah fi surah al Anfal, (Cairo: Daar al Tauzi' wa al Nasyr al Islamiyah, 1996), h. 16

${ }^{10}$ Maktabah Syamilah, Tafsir Ibnu Katsir (Surah al Anfaal ayat 2), h. 177. 
ayat Allah maka bertambahlah iman mereka), Ibnu Abbas mengatakan meyakini kebenaran ayat-ayat Allah (dan hanya kepada Tuhan mereka bertawakkal), tidak mengaharapkan sesuatu selain keridaan-Nya.

Dalam tafsir al Thabari dinyatakan bahwa mukmin sejati adalah ia yang apabila mendengar nama Allah disebut maka hatinya akan bergetar. Hal tersebut terjadi karena dalam hatinya tertanam rasa takut akan azab Tuhan apabila perilakunya bertentangan dengan syariat Allah dan rasul-Nya dan khudhu' dalam zikirnya. ${ }^{11}$

Berdasarkan ayat di atas, dapat ditarik suatu pendapat bahwa untuk menanamkan suatu pendidikan dimulai dari kalbu atau hati. Hati harus terisi dengan keimanan yang murni dan mantap hanya kepada Allah. Jika kalbu atau hati telah dapat merasakan adanya Allah (zikrullah) berarti seseorang tersebut dapat dikatakan telah mencintai Allah. Jika telah mencintai berarti dengan suka hati dan ikhlas mentaati perintah Allah yang lainnya. Hal ini didukung firman Allah pada surah yang sama ayat 74 , yaitu:

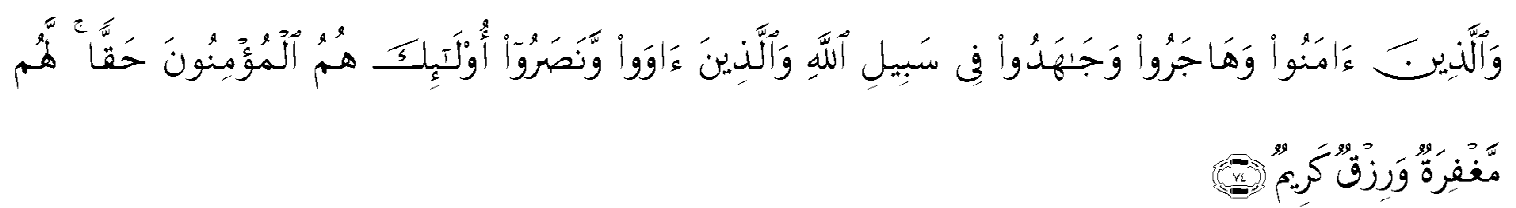

Dan orang-orang yang beriman dan berbijrah serta berjihad pada jalan Allah, dan orang-orang yang memberi tempat kediaman dan memberi pertolongan (kepada orang-orang Mubajirin), mereka Itulah orang-orang yang benar-benar beriman. mereka memperoleh ampunan dan rezki (nikmat) yang mulia.

Ayat di atas mengisyaratkan bahwa orang yang terisi hatinya dengan iman dan dengan karakteristik keimanan seperti di atas, maka orang tersebut sanggup berhijrah meninggalkan kampung halamannya, tempat kelahirannya bahkan keluarga dan kerabatnya demi mencapai rida Allah swt. kemudian ia mampu melakukan jihad baik dengan harta bahkan jiwa sekalipun.

Pendidikan yang beriorentasi pada hati sangat ditekankan dalam pendidikan Islam, karena dari hati akan mewarnai seluruh perbuatan individu, sebagaimana hadits Nabi saw berikut ini:

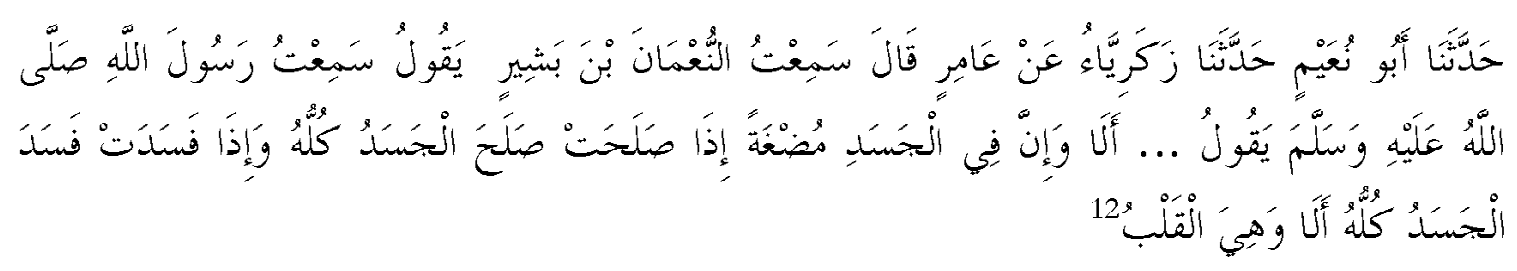

Artinya:" Berkata Abu Na'im, berkata Zakaria, dari 'Amir berkata, Aku mendengar Nu'man bin Basyir berkata, Aku mendengar Rasulullah saw bersabda:... Babwasanya di dalam jasad (badan) terdapat segumpal daging, jika baik maka baiklah selurub jasad, dan jika rusak maka rusaklah seluruh jasad yaitu adalah qalbu (hati)".

\footnotetext{
${ }^{11}$ Tafsir al Thabari, bab 2, juz 13, Maktabah Syamilah, h. 385

${ }^{12}$ Maktabah Syamilah,Kitab Shahih Bukhari, Bab Fadhlu man Istibraa li Dinihi, Juz 1, h. 90

${ }^{13}$ M. Quraish Shihab, Tafsir al Misbah: Pesan, Kesan, dan Keserasian al Qur'an, Volume 4, (Jakarta: Lentera Hati, 2010), h.
} 


\section{Pendidikan tentang Optimisme (Rajaa)}

Pada pembahasan di atas salah satu karakteristik orang beriman adalah bertawakal kepada Allah swt. Tawakal dapat diartikan sebagai penyerahan diri secara totalitas kepada Allah swt setelah melakukan usaha yang maksimal. Adapun hasilnya adalah berharap (rajaa/optimis) dengan berprasangka baik kepada Allah swt, karena menyadari bahwa manusia tidak memiliki kemampuan mendatangkan manfaat dan tidak pula mempunyai kekuatan untuk menampik mudarat. ${ }^{13}$ Allah berfirman dalam al Anfâl: 9 dan 10:

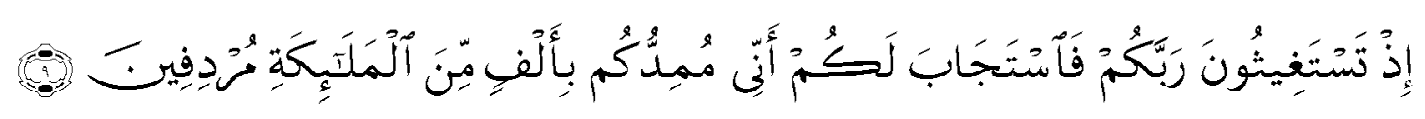

(ingatlab), ketika kamu memohon pertolongan kepada Tuhanmu, lalu diperkenankan-Nya bagimu: "Sesungguhnya Aku akan mendatangkan bala bantuan kepada kamu dengan seribu malaikat yang datang berturut-turut".

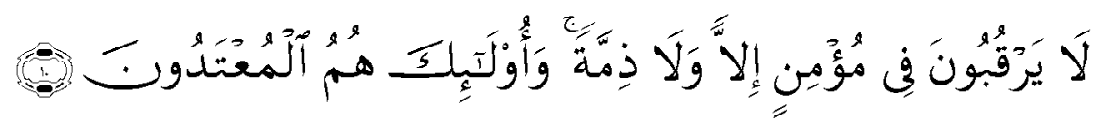

Mereka tidak memelihara (bubungan) kerabat terhadap orang-orang mukmin dan tidak (pula mengindabkan) perjanjian. dan mereka Itulah orang-orang yang melampaui batas.

Ayat di atas mengambarkan bahwa peristiwa perang Badar mendapat pertolongan dari Allah swt. Padahal jumlah pejuang umat Islam tidak sebanding dengan kaum musyrikinin Mekkah. Ayat tersebut dideskripsikan melalui hadits yang berasal dari Umar bin Khattab berikut ini:

$$
\begin{aligned}
& \text {.. عمر بن اللخطاب، رضي الله عنه، قال: للا كان يوم بدر نظر النبي صلى الله عليه وسلم إلى } \\
& \text { أصحابه، وهم تثلائائة وَنَّف، ونظر إلى المشر كين فإذا هم ألف وزيادة، فاستقبل النبي صلى الله عليه }
\end{aligned}
$$

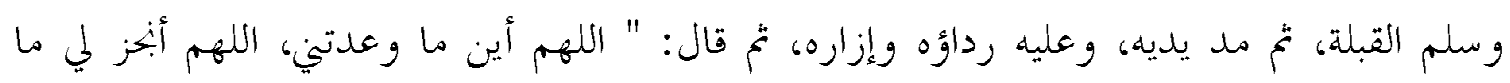

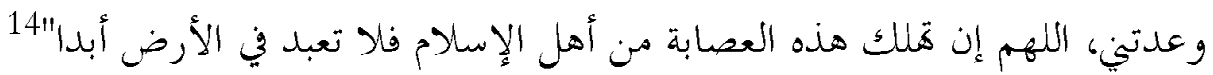

Artinya: "Umar bin Khattab r.a. berkata: bahwa pada perang Badar, Nabi Saw kepada sahabatshabatnya yang hanya berjumlah sekitar tiga ratus orang, dan melihat kaum musyikin yang berjumlah seribu orang. Maka Nabi saw menghadap ke Kiblat sambil mengangkat kedua tangan dan berdoa: "Ya Allah, penubilah apa yang Engkau janjikan padaku, penubilab apa yang Engkau janjikan padaku, Ya Allah jika Engkau membinasakan kelompok umat Islam ini, maka Engkau tidak disembah lagi di bumi." 15

Dalam Quraish Shihab hadits di atas dilanjutkan sebagai berikut: Nabi terus berdoa sambil mengulurkan tangannya sehingga serbannya terjatuh dari bahunya. Abu Bakar r.a mendatangi beliau dan mengambil serban tersebut kemudian meletakkan di bahu beliau lalu berdiri di

${ }^{14}$ Maktabah syamilah, Tafsir Ibnu Katsir (Surah al Anfaal ayat 2), h. 178

${ }^{15}$ M. Quraish Shihab, Tafsir al Misbab: Pesan, Kesan, dan Keserasian al Qur'an, Volume 4, (Jakarta: Lentera Hati, 2010), h. 474. 
hadapannya dan berkata: "Cukuplah permohonanmu kepada Tuhanmu karena sesungguhnya Dia akan memenuhi janji-Nya untukmu". Maka turunlah ayat 9 surah al Anfâl di atas, dimana Allah mendukung Nabi dengan menurunkan para malaikat. ${ }^{16}$

Doa merupakan kekuatan dalam terwujudnya suatu harapan atau cita-cita dan sangat dianjurkan untuk selalu mengiringi usaha dengan berdoa sepenuh hati kepada Allah. Bahkan, arti shalat sendiri dari segi bahasa bermakna doa yang berarti bagi seorang mukmin paling tidak 17 kali sehari berdoa. Doa akan memberikan kekuatan yang pada gilirannya menimbulkan rasa optimis (rajaa) akan keberhasilan terhadap usaha yang dilakukan. Jadi, doa merupakan ibadah sebagaimana hadits Nabi berikut ini:

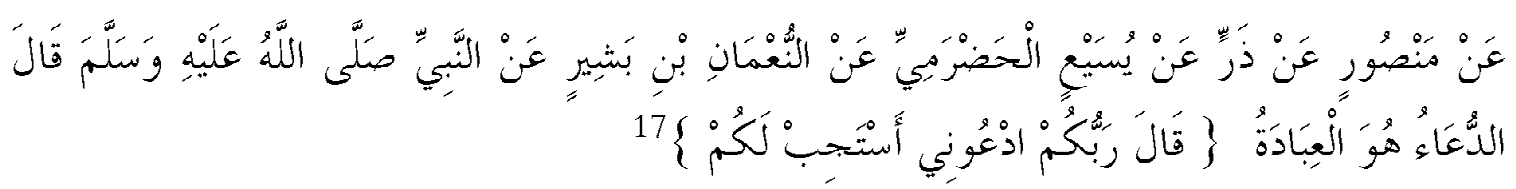

Agar doa senantiasa diijabah oleh Allah, maka seharusnya ia berprasangka baik kepada Allah swt, sebagaimana Hadist Qudsi berikut ini:

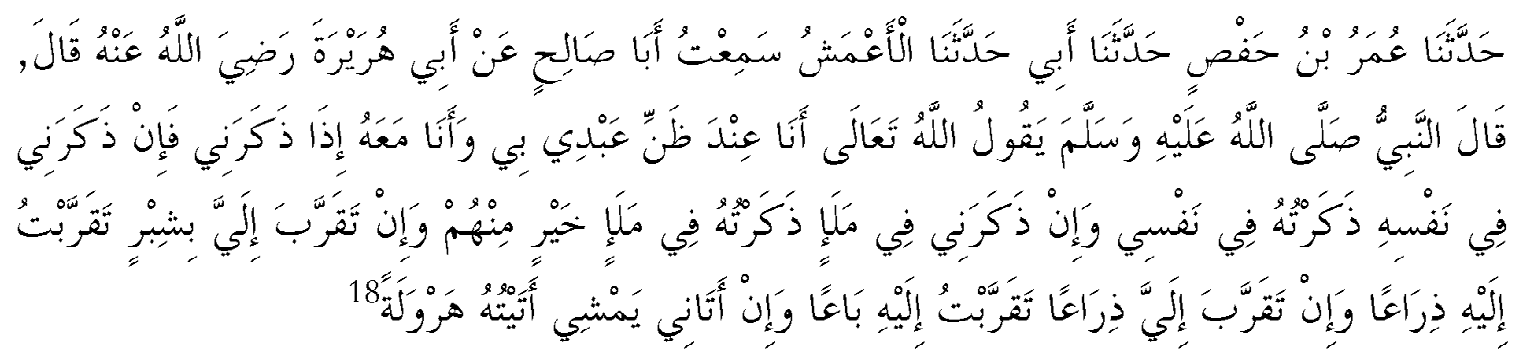

Mengabarkan kapada kami Umar bin Hafshi, dari Bapak, dari al A'Masy, Aku mendengar Abu Shaleh dari Hurairah r.a. berkata, Rasulullah saw bersabda; Allah swt berfirman: "Aku sesuai dengan prasangka hambaku terhadap-Ku, dan Aku berada bersamanya, jika ia mengingatku, apabila ia mengingat-Ku di dalam dirinya, Aku akan mengingatnya dalam diri-Ku, jika ia mengingat-Ku dalam menolong, Aku akan mengingatnya dalam menolong kebaikan dari mereka, jika ia mendekat padaKu sejengkal, Aku akan mendekat kepadanya sehasta, jika mendekat kepada-Ku sehasta Aku akan mendekat kepadanya satu depa, jika ia datang kepada-Ku dengan berjalan Aku akan datang kepadanya dengan berlari."

Hadits Qudsi di atas menggambarkan perhatian Allah kepada seorang hamba sesuai dengan apa yang dipikirkan hamba-Nya. Jika ia berprasangka baik, maka Allah akan memberikan yang baik pula, namun, jika tidak maka sebaliknya akan berlaku ketentuan terhadap dirinya. Dengan demikian, pendidikan untuk selalu optimis dan berprasangka baik (busnuz zhan) kepada Allah harus menjadi perhatian bagi pendidik agar terbentuk pribadi yang optimis ( raja) syukur terhadap nikmat Allah dan sabar terhadap ketentuan-Nya yang berlaku atas dirinya. Meskipun sesuatu yang terjadi sangat tidak menyenangkan (mushibah), akan tetapi ia tetap berprasangka baik kepada Allah swt.

\footnotetext{
${ }^{16}$ M. Quraisy Shihab, Ibid, h 475.

${ }^{17}$ Maktabah Syamilah, Kitab Sunan Abu Daud, bab Ad Do'a, Juz 44, h. 278

${ }^{18}$ Maktabah Syamilah, Kitab Shabih Bukhary, Bab, Qaululllah Ta'ala wa Yuhadzikumullah, Juz 22, h. 409
} 


\section{Pendidikan Jihad fi Sabilillah}

Secara etimologis, kata jihad terambil dari kata jahd yang berarti letih/sukar. Jihad tentu sulit dan menyebabkan keletihan. Jihad juga dikatakan berasal dari akar kata jubd yang berarti kemampuan.

Berjihad merupakan kewajiban bagi setiap muslim untuk tegaknya agama Allah di bumi ini. Al Qur'an telah memberikan rambu-rambu tentang jihad, macam-macam jihad yang tidak selalu diartikan dengan melawan musuh dalam peperangan. Seorang mukmin diwajibkan berhijrah dan berjihad dengan harta dan jiwa di jalan Allah swt, seperti pada ayat 75 surah al Anfâl berikut ini:

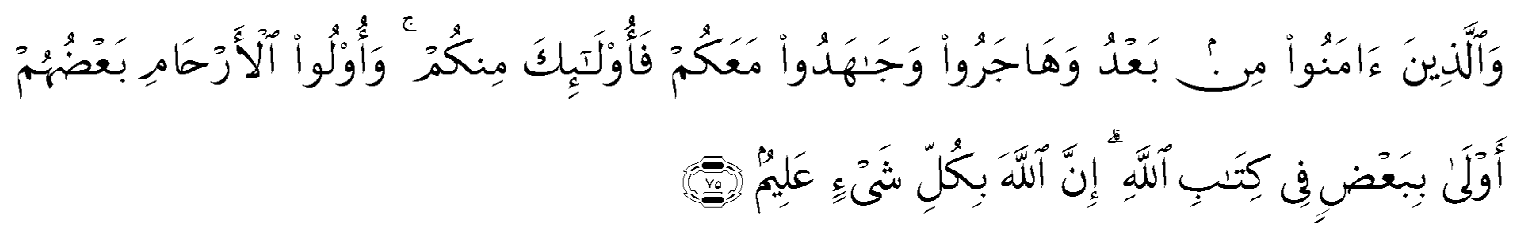

Dan orang-orangyang beriman sesudah itu Kemudian berbijrah serta berjihad bersamamu Maka orangorang itu termasuk golonganmu (juga). orang-orang yang mempunyai bubungan kerabat itu sebagiannya lebih berhak terhadap sesamanya (daripada yang bukan kerabat) di dalam Kitab Allah. Sesunggubnya Allah Maha mengetahui segala sesuatu.

Dari ayat di atas dapat dinyatakan bahwa jihad tidak hanya diperuntukkan berperang, akan tetapi melakukan perjuangan yang lebih luas dalam berbagai bidang kehidupan. Dengan demikian, seluruh amal ibadah, salat, puasa, haji, mencari nafkah, mencukupi kebutuhan keluarga, berdakwah, belajar, mengajar, sedekah, jika dilakukan dengan ikhlas, ditujukan untuk meninggikan kalimat Allah dan mencari keridaan-Nya maka hal tersebut dapatlah dikatakan sebagai jihad. ${ }^{19}$ Dengan kata lain, tidak ada satu amalan keagamaan yang tidak disertai dengan jihad. Paling tidak, jihad diperlukan untuk menghambat godaan nafsu yang mengajak pada kedurhakaan dan pengabaian tuntunan agama. ${ }^{20}$

Menurut Hasan al Banna pendidikan jihad/perjuangan tidak hanya terbatas pada pendidikan kemiliteran, sebab arti atau makna perjuangan jauh lebih luas daripada makna kemiliteran, sedang makna jihad yang dimaksudkan adalah makna iman, akhlak, semangat dan kesiapan. ${ }^{21}$

Adapun jihad seperti yang diungkapkan M. Dawam Rahardjo adalah perjuangan dengan motif dan tujuan keagamaan. Jadi, jihad tidak identik dengan perang. Hal ini merupakan persoalan mendasar, karena jika tidak diluruskan akan menyebabkan pengertian yang keliru bahwa Islam disebarkan dengan pedang dan merupakan agama kekerasan. Padahal dalam al Baqarah 2: 256 dinyatakan bahwa "tiada paksaan dalam agama, karena sesunggubnya yang benar telah jelas bedanya dengan yang salab”. Jadi, penyebaran agama dilakukan dengan cara damai. Al Qur'an pun mengajarkan bahwa Allah tidak mengharapkan orang menjadi beriman dengan cara kekerasan, melainkan dengan jalan studi, refleksi, dan kontemplasi. ${ }^{22}$

\footnotetext{
${ }^{19}$ A hmadi Sofyan, Islam on Jihad, (Jakarta: Lintas Pustaka, 2006), h. 67

${ }^{20}$ M. Quraish Shihab, Wawasan al Qur'an: Tafsir Maudhu'i atas Pelbagai Persoalan umat, (Bandung: Mizan, 1997), h. 503

${ }^{21}$ Yusuf al Qardhawy, Pendidikan Islam dan madrasah Hasan al Banna, alih bahasa: Bustami A Gani \& Zainal Abidin Ahmad, (Jakarta: Bulan Bintang, 1980), h. 73

${ }^{22}$ M. Dawam Rahardjo, Ensiklopedi al Qur'an: Tafsir Sosial Berdasarkan Konsep-konsep Kunci, (Jakarta: Paramadina, 1996), h. 512.
} 
Dalam konteks surah al Anfâl, berjuang atau berjihad yang dimanifestasikan dengan berperang dinyatakan harus dilakukan dengan tulus jiwa raga dan tidak boleh lari atau mundur dari peperangan kecuali hanya untuk mengatur siasat sebagaimana firman Allah ayat 15 dan 16 surah al Anfâl ini:

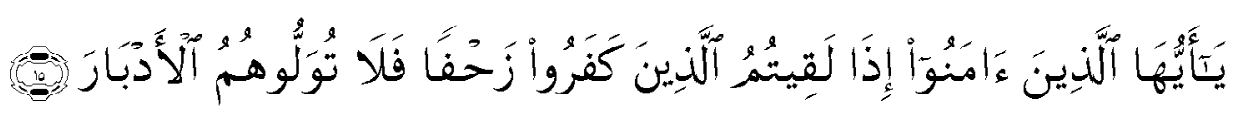

Hai orang-orang yang beriman, apabila kamu bertemu dengan orang-orang yang kafir yang sedang menyerangmu, maka janganlah kamu membelakangi mereka (mundur).

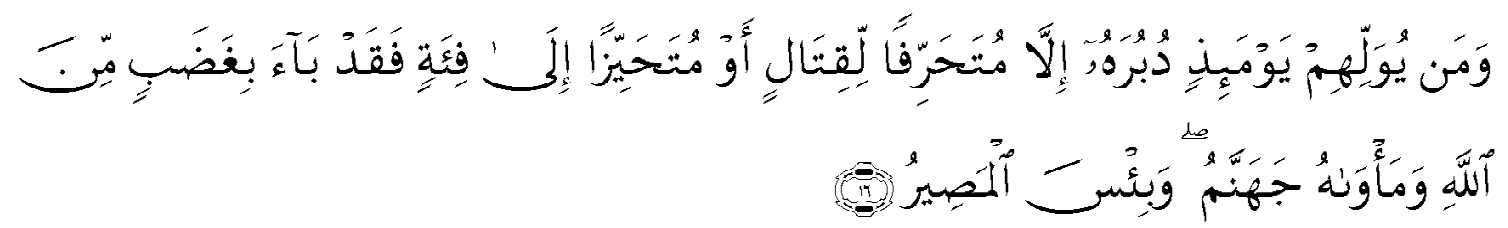

Barangsiapa yang membelakangi mereka (mundur) di waktu itu, kecuali berbelok untuk (sisat) perang atau hendak menggabungkan diri dengan pasukan yang lain, Maka Sesunggubnya orang itu kembali dengan membawa kemurkaan dari Allah, dan tempatnya ialah neraka jahannam. dan amat buruklah tempat kembalinya.

Jihad merupakan bagian yang tidak dapat dipisahkan dari kehidupan seorang muslim. Bahkan, kedudukannya termasuk salah satu amal atau perbuatan utama sebagaimana hadits Nabi berikut ini.

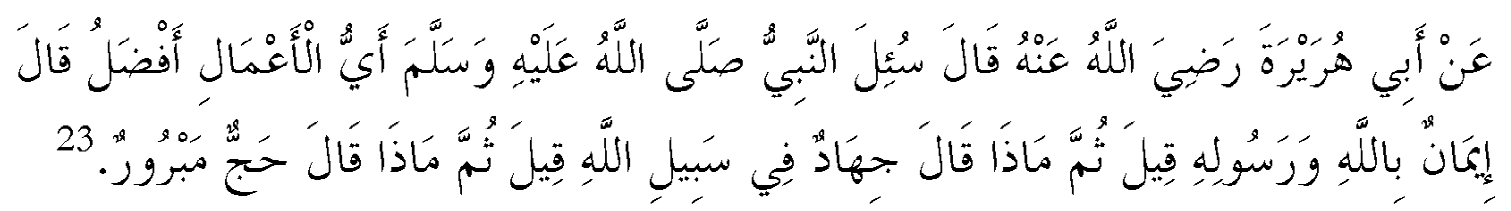

'Dari Abu Huraira r.a. berkata: Nabi saw ditanya Amal apakah yang paling utama, Beliau bersabda; Beriman kepada Allah dan Rasul-Nya, kemudian apa lagi? Berjibad di jalan Allah, lalu apa lagi? Haji yang mabrur".

Jadi, jihad merupakan hal yang utama bagi seorang mukmin karena jihad merupakan amal utama setelah beriman kepada Allah dan rasul. Jihad merupakan puncak usaha tertinggi seorang muslim di dunia dan orang yang berjihad akan memperoleh tempat terbaik di sisi Allah dan kemuliaan di dunia. ${ }^{24}$

\section{Pendidikan Berlaku Sabar}

Perkataan sabar terasa ringan bila diucapkan dengan lisan tetapi sangat berat bila diimplemntasikan dalam kehidupan sehari-hari. Sabar tidak ada batasnya dan Islam sangat menganjurkan umatnya untuk berlaku sabar dalam melaksanakan kewajiban, ketaatan, berdakwah, sampai kepada sabar terhadap menahan diri dari tidak melaksanakan maksiat

\footnotetext{
${ }^{23}$ Maktabah Syamilah (Hadits digital), Kitab Shabih Bukhary, Bab Fadl al Haj al Mabrur, Juz 5, h. 398

${ }^{24} \mathrm{Al}$ Imam Muhammad bin abdul Wahhab, Mukhtashar Zaadul Ma'ad: Ibnu Qoyyim al-Jauziyah, Alih Bahasa: Marsuni al-Sasaky, (Jakarta: Akbar Media Eka Sarana, 2008), h. 149
} 
kepada Allah. Seseorang yang sabar akan menahan diri, dan untuk itu ia memerlukan kekukuhan jiwa dan mental baja agar dapat mencapai ketinggian yang diharapkannya, yakni rida Allah. Firman Allah pada ayat 65 surah al Anfâl berbunyi:

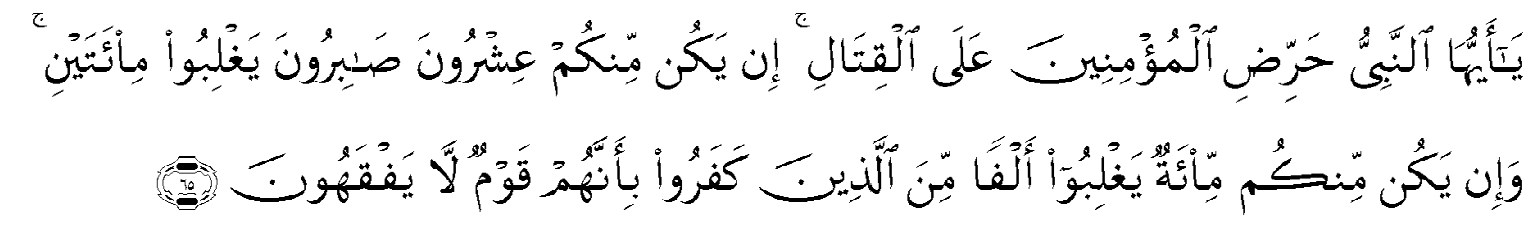

Hai nabi, kobarkanlah semangat para mukmin untuk berperang. jika ada dua puluh orang yang sabar di antaramu, niscaya mereka akan dapat mengalabkan dua ratus orang musuh. dan jikea ada seratus orang yang sabar di antaramu, niscaya mereka akan dapat mengalabkan seribu dari orang kafir, disebabkan orang-orang kafir itu kaum yang tidak mengerti.

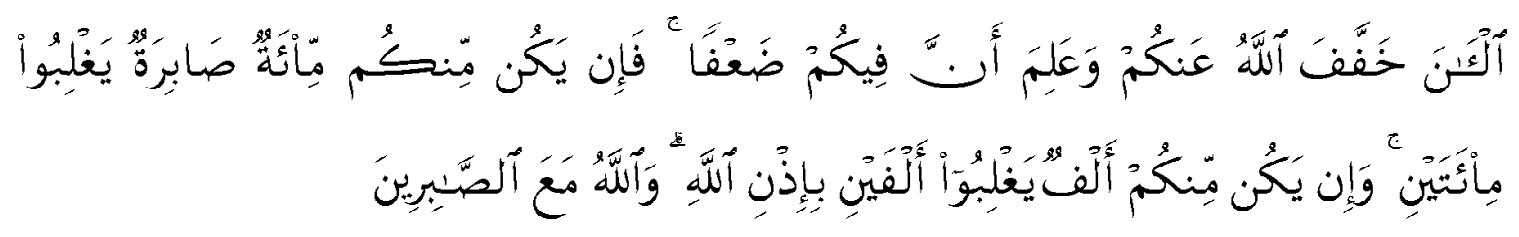

Sekarang Allah telah meringankan kepadamu dan Dia telah mengetahui bahwa padamu ada kelemahan. Maka jika ada di antaramu seratus orang yang sabar, niscaya mereka akan dapat mengalabkan dua ratus orang kafir; dan jika diantaramu ada seribu orang (yang sabar), niscaya mereka akan dapat mengalabkan dua ribu orang, dengan seizin Allah. dan Allah beserta orang-orangyang sabar.

Menurut al Kalbi ayat di atas turun di Baida, pada saat perang Badar sebelum pertempuran berkecamuk. Sementara itu, Ibnu Abbas berkata. "Allah mewajibkan satu orang muslim bertempur melawan sepuluh orang kafir, namun kaum muslimin merasa keberatan dan tidak mampu, Allah kemudian memutuskan bahwa setiap satu orang bertempur melawan dua orang musuh, Allah pun menurunkan ayat tersebut." 25

Menurut Quraish Shihab pada ayat 65 Allah menyatakan kaum mukminin dapat mengalahkan kaum musyrikin dengan perbandingan 1:10, disebabkan karena selain bantuan Allah juga karena mereka memiliki pengertian yang mendalam terhadap persoalan yang samar, tersembunyi, lagi terperinci. Dalam hal ini mereka mengarahkan pandangan pada sisi mental, menyadari bahwa ketakwaan pada Allah merupakan kekuatan yang ampuh melebihi kecanggihan senjata dan jumlah personil.

Adapun pada ayat 66 Allah menetapkan hukum yang baru, yakni 1:2. Hal ini karena terdapat orang munafik di kalangan kaum muslimin sehingga terdapat faktor yang melemahkan. Namun, peperangan berhasil dimenangkan kaum muslimin karena kesabaran yang dimiliki, dimana mereka dapat menahan diri untuk tidak gentar dan lari, memiliki kekukuhan jiwa dan bermental baja untuk dapat mencapai ketinggian yang mereka harapkan. Ini berarti dengan kesabaran saja seorang prajurit muslim dapat melawan dua orang kafir. Tetapi, bila ia memiliki pengertian yang mendalam, maka ia mampu menghadapi 10 orang kafir.

${ }^{25}$ Wahbah Zuhaili, dkk, Buku Pintar al Qur'an Seven in One, (Jakarta: al Mahira, 2009), h. 186 
Jika keadaannya kembali normal, yakni hal-hal yang melemahkan tidak muncul, maka ketentuan hukum ayat 65 yakni 1:10 kembali berlaku. Dengan demikian, ayat 65 tidak dibatalkan hukumnya dengan datangnya ayat 66. Jadi, 1:10 merupakan hukum dasar perbandingan seorang mukmin dengan kafir jika terjadi pertempuran.

Sabar memiliki kekuatan yang dahsyat, bahkan di akhir ayat 66 pun ditutup dengan kalimat dan Allah bersama orang-orang yang sabar. Adapun hadits Nabi saw yang berkenaan dengan sabar berbunyi:

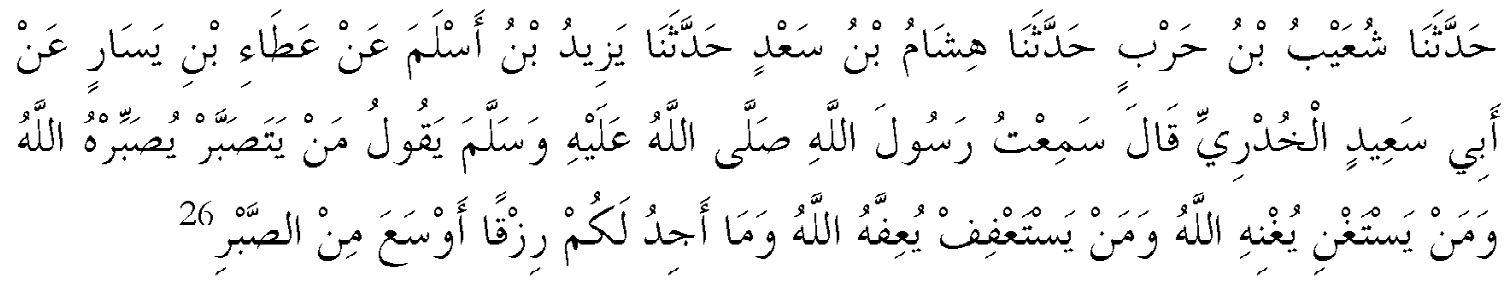

Berkata syuaib bin Harb, berkata bisyam bin Sa"d berkata Yazid bin Aslam dari Atha' bi Yasar dari Abu sa'id al Khudry berkata; Aku mendengar Rasulullah saw bersabda: Barangsiapa bersabar Allah akan memberikan kesabaran padanya, barangsiapa merasa cukup Allah akan mencukupinya, dan siapa yang memaafkan Allah akan memaafkannya, diberikan Allah rezeki lebih luas karena sabar.

\section{Simpul-Simpul Pendidikan pada Surah At Taubah}

\section{Sekilas tentang surah At Taubah}

Surah at Taubah juga disebut surah Baraah. Surah ini diturunkan 15 bulan sebelum wafat baginda Nabi saw. Surah ini termasuk salah satu surah madaniyah, yakni setelah dua puluh tahun berlangsung turunnya wahyu. ${ }^{27}$ Nama lain dari surah al Taubah adalah al Muqasyqisyah (yang menyembuhkan/ yang membersihkan) dari kemusyrikan dan kemunafikan. Ia juga dinamai dengan al fadhihah (pembuka rahasia), yang dalam hal ini dikatakan oleh Ibnu 'Abbas, yakni "Surah ini silih berganti ayat-ayatnya yang turun menyatakan dan di antara mereka...dan di antara mereka sehingga kami menduga bahwa tidak akan ada lagi yang tidak disebut namnya (dipermalukan dan dibongkar rahasianya)". ${ }^{28}$ Sahabat Nabi saw, Hudzaifah, menamai surah ini dengan surah al 'Azab, karena ayat-ayatnya berbicara tentang siksa terhadap orang-orang kafir. Selain itu, surah ini dinamai juga dengan al Munqirah (yang melubangi), yakni melubangi hati orang-orang munafik sehingga penipuan yang terpendam di hati mereka serta niat busuk mereka terbongkar dan muncul ke permukaan. Ulama sepakat bahwa surah ini merupakan surah yang terakhir yang diterima nabi saw turun setelah surah al Fath (surah ke 110) dalam perurutan Mushaf dan surah ke 114 dari segi jumlah surah-surah al Qur'an yang turun kepada Nabi Muhammad saw). ${ }^{29}$

\footnotetext{
${ }^{26}$ Maktabah Syamilah (Hadits Digital), Kitab Musnad Ahmad, Juz 22, h. 214

${ }^{27}$ Muhammad al Muallim, Nahwu Tafsir al Maudbu'I Li Suwar al Qur;an al Karim, (Daru al Syuruf, Cairo, 1995), h. 141

${ }^{28}$ Ali Abd al Him mahmud, al Tarbiyah al Islamiyah fi surah al Taubah, (Cairo: Daar al Tauzi' wa al Nasyr al Islamiyah, 1998), h. 18

${ }^{29}$ M. Quraish Shihab, Tafsir al Misbah: Pesan, Kesan, dan Keserasian al Qur'an, Volume 5, (Jakarta: Lentera Hati, 2010), h. $3-4$
} 
Surah al Taubah merupakan satu-satunya surah yang tidak diawali Basmalah dalam penulisannya. Pembahasan tersebut di kalangan ulama menimbulkan berbagai pendapat yang berlainan. Yusuf al Qardawi menyatakan dari beberapa pendapat ia lebih condong pada pernyataan Ali bin Abi Thalib. Ali bin Abi Thalib menerangkan: "Bismillabi al Rabman al Rabim adalab adalah pernyataan aman, sedangkan surah Baraah turun untuk mencabut jaminan keamanan". Kalimat di atas diterangkan oleh Ibnu al Jauzi: "Surah-surah yang didahului dengan Basmalah turun dalam suasana perdamaian antara kaum muslimin dan kaum musyrikin Quraisy, sedangkan sural Baraah turun justru untuk membatalkan perjanjian perdamaian antara kaum tersebut". ${ }^{30}$

Surah al Taubah merupakan pernyataan umum mengenai berakhirnya perjanjian antara kaum muslimin dan kaum musyrikin Quraisy. Selama kaum musyrikin masih melakukan kejahatan, menganiaya dan menyiksa, bekerjasama dengan Yahudi, berkhianat terhadap kaum muslimin, tak ada lagi perjanjian damai, tidak ada jaminan keamanan dan keselamatan terhadap mereka. Oleh karena itu, turunnya surah al Taubah menegaskan bahwa Allah dan Rasul-Nya berlepas tangan terhadap mereka. ${ }^{31}$

Riwayat lain mengatakan bahwa surah al Anfâl adalah surah pertama yang diturunkan di Madinah dan sementara surah Baraah (at Taubab) adalah surah terakhir. Uraiannya sangat mirip (hampir serupa) dengan uraian surah al Anfâl, di antaranya dorongan untuk berjihad, berinfak, kerja sama dan bantu membantu antarmuslim. Selain itu, terdapat pula uraian tentang keadaan Nabi saw pada awal periode perjuangan beliau, pertengahan, dan akhirnya. Hal ini berpengaruh pada ketiadaan Basmalah dalam surah al Taubah, seperti yang dikemukakan Usman bin 'Affan.

Menurut Usman bin Affan r.a. aku menduga surah Bara'ah adalah bagian dari surah al Anfâl, Rasulullah saw wafat sebelum sempat menjelaskannya di mana harus diletakkan, karena itu Aku kata Usman r.a. memerintahkan meletakkannya sesudah surah al Anfâl dan tidak menuliskan Basmalah antara keduanya. Hal ini seperti yang ditemukan dalam tafsir Ibnu Katsir sebagai berikut:

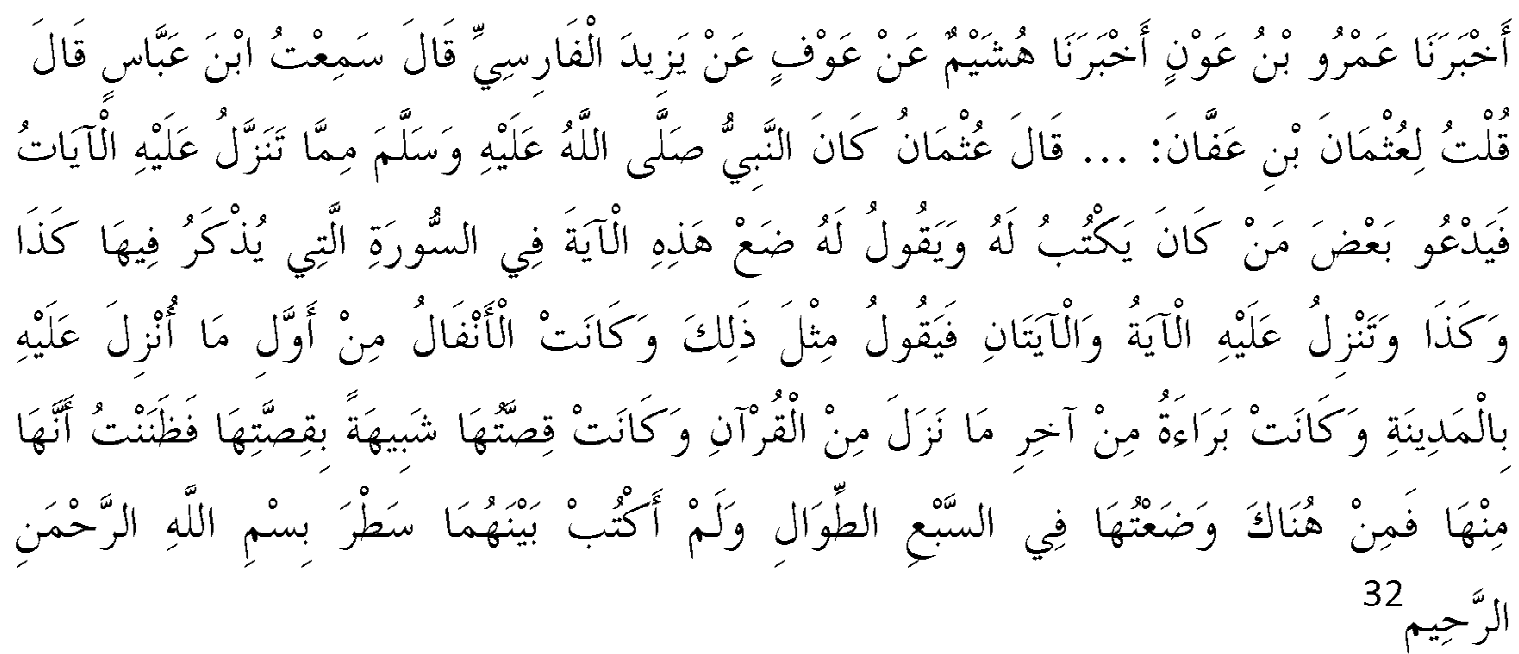

${ }^{30}$ Yusuf al Qardhawi, Fatwa-fatwa Mutakhir, alih bahasa: H.M.H. al Hamid al Husaini, (Bandung: Pustaka Hidayah, 2000), h. 72

${ }^{31}$ Yusuf al Qardhawi, Ibid, 2000, h. 73

${ }^{32}$ Maktabah Syamilah (Hadits Digital) Kitab Sunan Abu Daud, Bab Man Jahara biha, juz 2 h. 440 
Para kritikus Hadits menyatakan dalam rangkaian perawi riwayat di atas terdapat seorang yang bernama Yazid al Farisi yang diragukan identitasnya atau paling sedikit tidak dikenal identitasnya. Atas dasar tersebut riwayat ini sanadnya sangat lemah. Sementara kandungan informasi (matan) sulit diterima. Apakah masuk akal Rasulullah tidak menjelaskan tempat surah bingga beliau wafat, padahal jarak antara turunnya surah ini dengan wafatnya Rasulullah saw masih sangat cukup panjang ${ }^{33}$, yakni 15 bulan sebelum beliau wafat.

Terakhir menurut Quraisy Shihab, semua pendapat di atas merupakan ijtihad atau hasil pemikiran manusia, dan tidak memiliki pijakan yang kuat tidak juga ada dasarnya dari Rasul saw. Boleh jadi jawaban yang relevan adalah surah ini memang tidak dimulai dengan Basmalah, karena Rasul saw sendiri tidak memerintahkan untuk menuliskannya. ${ }^{34}$ Adapun simpul-simpul pedidikan dalam surah At Taubah dapat diuraikan sebagai berikut.

\section{Pendidikan bahwa Muslim adalah bersaudara}

Firman Allah ayat 10 dan 11 berbunyi:

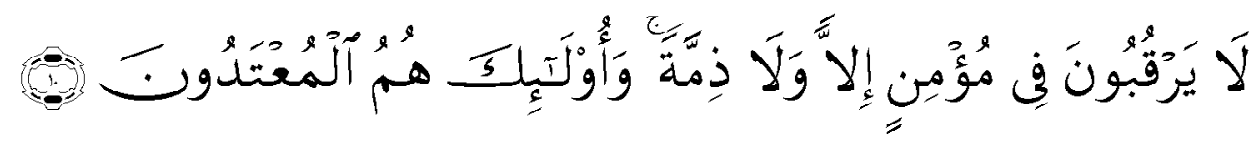

Mereka tidak memelihara (bubungan) kerabat terbadap orang-orang mukmin dan tidak (pula mengindabkan) perjanjian. dan mereka itulah orang-orang yang melampaui batas.

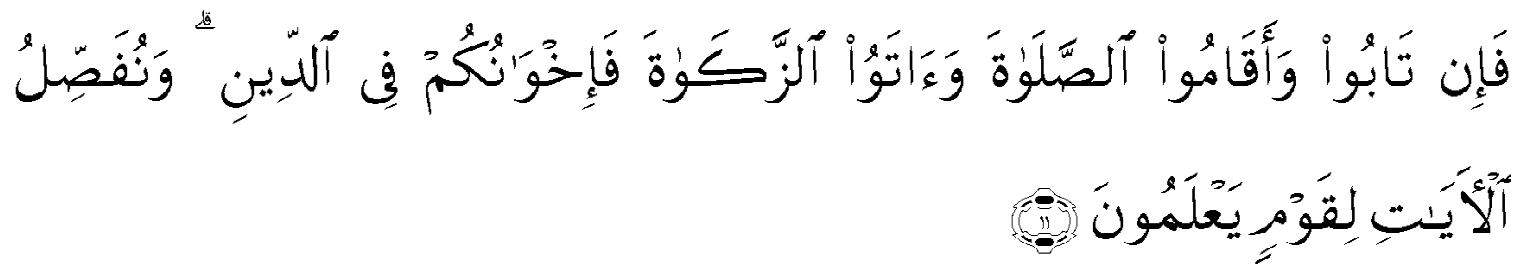

Jika mereka bertobat, mendirikan salat dan menunaikan zakat, maka (mereka itu) adalab saudarasaudaramu seagama dan kami menjelaskan ayat-ayat itu bagi kaum yang Mengetahui.

Ayat di atas, berbicara tentang orang munafik yang tidak memiliki hubungan kekerabatan dengan orang mukmin. Namun jika mereka bertobat, melaksanakan salat dan bersedia membayar atau menunaikan zakat, maka mereka adalah termasuk saudara seagama dengan orang mukmin lainnya.

Menurut Sayyid Quthub, jika mereka (munafik) bersedia masuk ke dalam agama yang dianut oleh kaum muslimin dan bertobat dari perilaku-perilaku masa lalu yakni syirik dan melakukan permusuhan dengan muslimin maka kaum muslimin akan terhindar dari segala perlakuan yang membahayakan yang dilakukan oleh kaum musyrikin yang melampau batas tersebut. Jika hal tersebut mereka lakukan maka kemudian terjalinlah ikatan persaudaraan yang berdasarkan azas akidah, dan komunitas muslim baru akan menjadi saudara bagi muslim yang lama. ${ }^{35}$

${ }^{33}$ M. Quraish Shihab, Tafsir al Misbah: Pesan, Kesan, dan Keserasian al Qur'an, Volume 5, (Jakarta: Lentera Hati, 2010), h. 5

${ }^{34}$ M. Quraish Shihab, 2010, Ibid, h. 6

${ }^{35}$ Sayyid Quthub, Tafsir Fi zhilal al Qur'an (di Bawah Naungan al Qur'an), alih bahasa: Sa’id Jilid 5, (Jakarta: Gema Insani Pres, 2003), h. 301 
Berdasarkan ayat dan penjelasan di atas dapat diambil pelajaran bahwa dengan bertobat (taubatan nashuha) maka seluruh dosa yang dilakukan di masa lalu akan diampuni oleh Allah swt. Dengan demikian, bagi manusia apapun bangsa, suku, bahasa dan warna kulitnya, kalau ia mengucap dua kalimat syahadat, menunaikan shalat, dan bersedia membayar zakat, meskipun ia tidak memiliki hubungan darah, dan kekerabatan maka mereka adalah saudara segama. Hal ini dipertegas dengan penjelasan Nabi sawa dimana mukmin yang satu dengan mukmin lainnya seumpama satu bangunan saling terikat atau saling menguatkan, seperti Hadits Nabi saw:

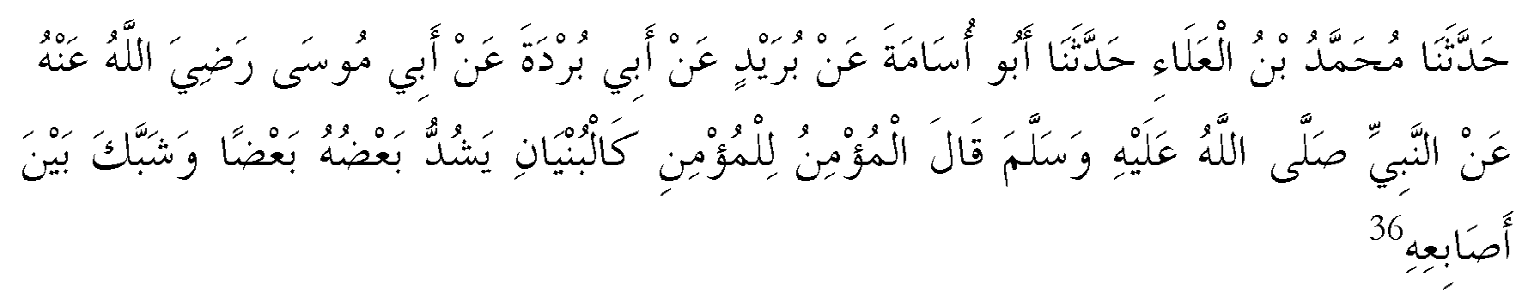

Berkata Mubammad bin Ala', berkata Abu Usamah, dari Buraid, dari Abu Burdah, dari Abu

Musa r.a. dari Nabi saw bersabda: Seorang mu'min dengan mukmin lainnya seperti bangunan yang saling menopang satu dengan lainnya, kemudian beliau memasukkan jari-jari tangan beliau.

Keterangan di atas menegaskan bahwa seorang muslim dan mukmin saling bersaudara satu dengan yang lainnya saling membantu dan menolong saudaranya, di samping itu juga ikut merasakan apa yang dirasakan saudaranya.

Persaudaraan seagama, ditandai dengan tiga sifat utama, yaitu pengucapan dua kalimat syahadat, yang oleh ayat di atas yang disebut dengan bertobat, sedang yang kedua dan ketiga adalah pelaksanaan shalat dengan baik dan penunaian zakat dengan sempurna. ${ }^{37}$

Pada surah ini ada beberapa ayat yang berbicara tentang persaudaraan antara golongan muhajirin dan anshar, yang satu sama lainnya saling membantu, dan menasehati dan Allah menyayangi dan meridai karena perbuatan mereka. ${ }^{38} \mathrm{Hal}$ tersebut digambarkan pada ayat 71 :

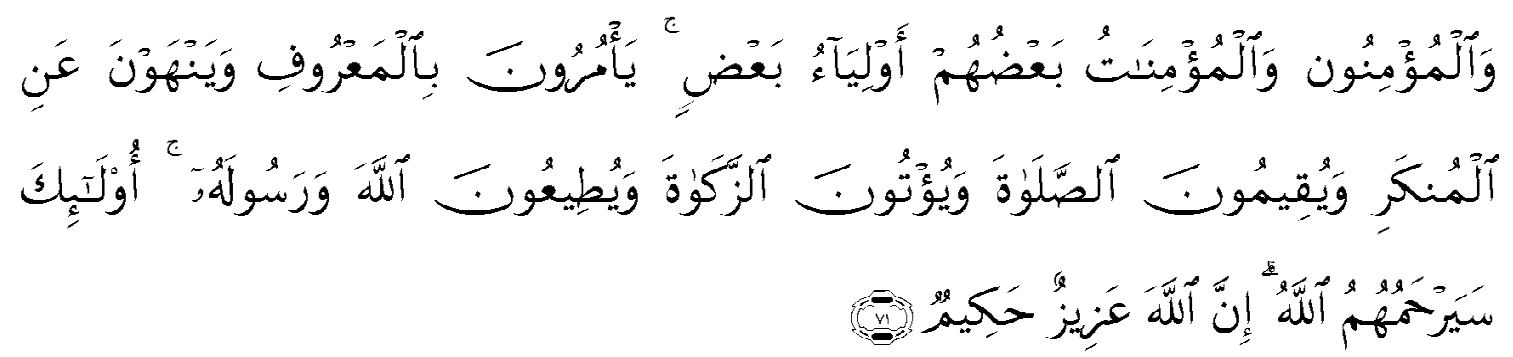

Dan orang-orang yang beriman, lelaki dan perempuan, sebahagian mereka (adalab) menjadi penolong bagi sebahagian yang lain. mereka menyuruh (mengerjakan) yang ma'ruf, mencegah dari yang munkar, mendirikan shalat, menunaikan zakat dan mereka taat pada Allah dan Rasul-Nya. mereka itu akan diberi rahmat oleh Allab; Sesungguhnya Allah Maha Perkasa lagi Maha Bijaksana.

\footnotetext{
${ }^{36}$ Maktab Syamilah (Hadits Digital), Kitab Shahih Bukhari, bab Nashru al Mazhlum, juz 8, h. 315

${ }^{37}$ M. Quraish Shihab, Tafsir al Misbah: Pesan, Kesan, dan Keserasian al Qur'an, Volume 5, (Jakarta: Lentera Hati, 2010$)$, h. 30

${ }^{38} \mathrm{Ali}$ Abd al Him Mahmud, al Tarbiyah al Islamiyah fi surah al Taubah, (Cairo: Daar al Tauzi’ wa al Nasyr al Islamiyah, 1998), h. 32
} 


\section{Cinta kepada Allah dan Rasul-Nya melebihi dari segalanya}

Pada ayat ke 24 surah at Taubah ini terdapat keengganan pada diri kaum muslimin untuk ikut hijrah ke Madinah bersama Nabi saw, karena lebih mementingkan keluarga dan perdagangannya, sehingga turunlah ayat berikut:

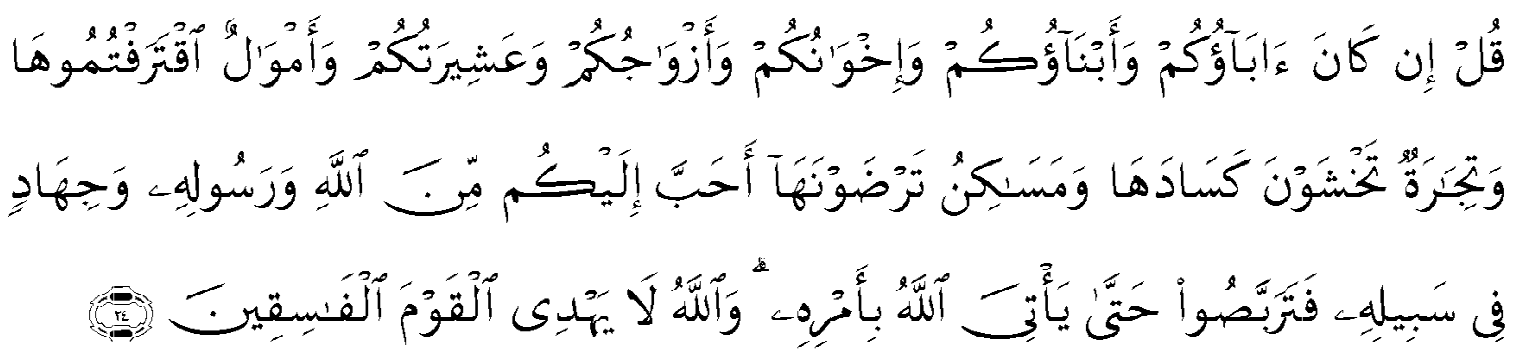

Katakanlab: "Iika bapak-bapak kalian, anak-anak, saudara-saudara, isteri-isteri, kaum keluargamu, harta kekayaan yang kamu usahakan, perniagaan yang kamu khawatiri kerugiannya, dan tempat tinggal yang kamu sukai, adalah lebih kamu cintai dari Allah dan Rasul-Nya dan dari berjihad di jalan-Nya, maka tunggulah sampai Allah mendatangkan Keputusan-Nya”. dan Allah tidak memberi petunjuk kepada orang-orang yang fasik.

Sebagai orang beriman, dibolehkan mencintai sesuatu namun hanya sekadarnya saja, sebab cinta yang sebenarnya hanyalah untuk Allah semata dan Rasul-Nya dan itulah ciri orang yang beriman, sebagaimana hadits Shahih berikut ini:

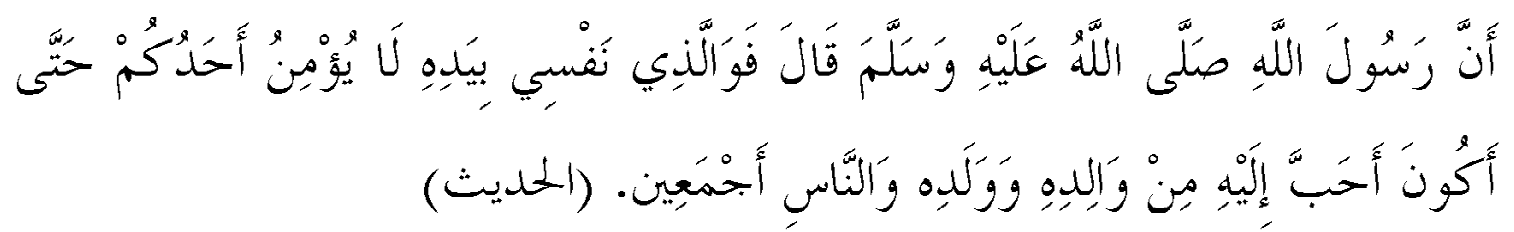

Rasulullah saw bersabda: Demi Tuhan yang jiwaku berada dalam genggeman kekuasaan-Nya, tidaklah beriman seseorang di antara kalian sebelum diriku ini lebih dicintai olehnya daripada orang tuanya, anak-anaknya, dan semua orang. ${ }^{39}$

Ayat ke 24 di atas tidak berarti melarang mencintai keluarga dan harta benda, karena hal tersebut merupakan naluri atau fitrah manusia. Ayat tersebut justru mengingatkan kepada kaum muslimin agar jangan sampai kecintaan pada hal-hal tersebut melampaui batas sehingga pilihan yang diambil mengorbankan kepentingan agama. Lebih lanjut, Quraish Shihab menjelaskan kecintaan terhadap sesuatu diukur ketika seseorang dihadapkan pada dua hal atau lebih yang harus dipilih salah satunya, sehingga cinta yang lebih besar akan terlihat saat pilihan ditetapkan. Namun, tidak selalu kepentingan duniawi dan kenikmatannya bertentangan dengan nilai-nilai Ilahi, dan ketika itu tidak ada salahnya jika keduanya digabung. Ancaman ayat di atas ditujukan pada situasi dimana diharuskan adanya pilihan menyangkut dua hal yang tidak dapat digabung. ${ }^{40}$

${ }^{39} \mathrm{Al}$ Imam Abu al Fida ismail Ibnu Kasir ad Dimasyqi, Tafsir Ibnu Katsir, Juz 9, (Bandung: Sinar baru Algensindo), 2005, h. 173

${ }^{40}$ M. Quraish Shihab, Tafsir al Misbab: Pesan, Kesan, dan Keserasian al Qur'an, Volume 5, (Jakarta: Lentera Hati, 2010), h. 56 


\section{Pendalaman Pengetahuan}

Anjuran yang demikian gencar, pahala yang demikian besar bagi yang berjihad, serta kecaman yang sebelumnya ditujukan kepada yang enggan menjadikan kaum mukmin berduyunduyun dan dengan penuh semangat maju ke medan juang. Hal ini dikatakan Allah tidak pada tempatnya, karena terdapat arena perjuangan lain yang juga harus dipikul. Dalam hal ini Allah berfirman pada al Taubah ayat 122:

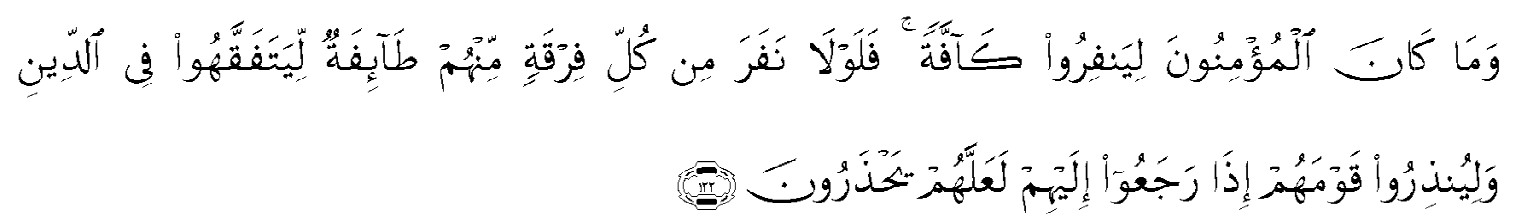

Tidak sepatutnya bagi mukminin itu pergi semuanya (ke medan perang). Mengapa tidak pergi dari tiap-tiap golongan di antara mereka beberapa orang untuk memperdalam pengetahuan mereka tentang agama dan untuk memberi peringatan kepada kaumnya apabila mereka Telah kembali kepadanya, supaya mereka itu dapat menjaga dirinya.

Menurut Baihaqi, kata thaifah dapat berarti satu atau dua orang. Ada juga yang tidak menentukan jumlahnya, namun ia lebih kecil dari firqah yang berarti sekolompok manusia yang berbeda dengan kelompok lain. Karena itu, satu suku atau bangsa dapat dinamai firqah." ${ }^{41}$ Namun, pada intinya Allah menghendaki agar kaum mukmin sebagian besar ikut berperang dan menyisakan sebagian kecil dari mereka untuk memperdalam segala macam pengetahuan, karena pembagian disiplin ilmu agama dan ilmu umum tidak dikenal sebab semua ilmu bersumber dari Allah. Menyiapkan diri untuk memusatkan perhatian dalam memperdalam pengetahuan termasuk ke dalam perbuatan yang tergolong mendapatkan kedudukan yang tinggi di hadapan Allah, dan tidak kalah derajatnya dari orang yang berjihad dengan harta dan dirinya dalam rangka meninggikan kalimat Allah. ${ }^{42}$

Menurut sebagian mufasir, perang dalam ayat tersebut hukumnya fardhu kifayah, dan apabila telah dilaksanakan oleh sebagian, maka gugurlah kewajiban yang lain. Jadi, bukan fardhu 'ain yang wajib dilakukan setiap orang. Perang barulah menjadi wajib apabila Rasul sendiri keluar dan mengarahkan kaum mukmin menuju medan perang. ${ }^{43}$ Dengan demikian, tujuan utama ayat ini adalah selain menggarisbawahi pentingnya memperdalam ilmu dan menyebarluaskan informasi yang benar, juga menggambarkan bagaimana seharusnya tugastugas dibagi sehingga tidak semua mengerjakan satu jenis pekerjaan saja. Bahkan, menurut Quraish Shihab tidak dapat dikatakan bahwa masyarakat Islam kini dan pada zaman Nabi hanya melakukan dua tugas pokok, yakni berperang dan menuntut ilmu agama, karena terdapat banyak tugas lain dan setiap masyarakat berkewajiban membagi diri guna memenuhi semua keperluannya. ${ }^{44}$ Selain itu, perang merupakan jalan terakhir yang ditempuh Nabi setelah dakwah

${ }^{41}$ M. Quraish Shihab, Ibid, 2010, h. 289

${ }^{42}$ Abuddin Nata, Tafsir Ayat-ayat Pendidikan: Tafsir al Ayat al Tarbawi, (Jakarta: PT RajaGrafindo Persada, 2010), h. 159

${ }^{43}$ Mahyuddin Barni, Pendidikan dalam Perspektif al Qur'an: Studi Ayat-ayat al Qur'an tentang Pendidikan, (Yogyakarta: Pustaka Prisma, 2011), h. 69.

${ }^{44}$ M. Quraish Shihab, Tafsir al Misbab: Pesan, Kesan, dan Keserasian al Qur'an, Volume 5, (Jakarta: Lentera Hati, 2010), h. 
dan upaya damai tidak dapat ditempuh dan perang ditujukan untuk memberantas aniaya dan ketidakadilan yang dilakukan kafir Quraisy terhadap kaum muslimin agar kebebasan dalam beribadah dalam rangka meninggikan kalimat Allah dapat dilakukan. ${ }^{45}$

\section{Pendidikan untuk Bertawakal}

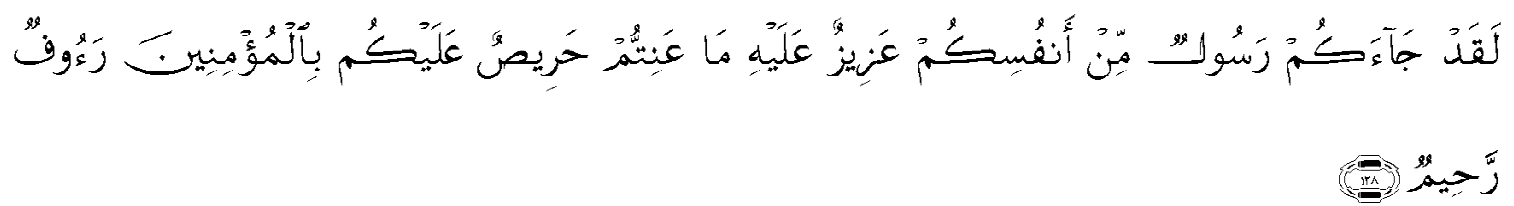

Sungguh Telah datang kepadamu seorang Rasul dari kaummu sendiri, berat terasa olehnya penderitaanmu, sangat menginginkan (keimanan dan keselamatan) bagimu, amat belas kasihan lagi Penyayang terhadap orang-orang mukmin.

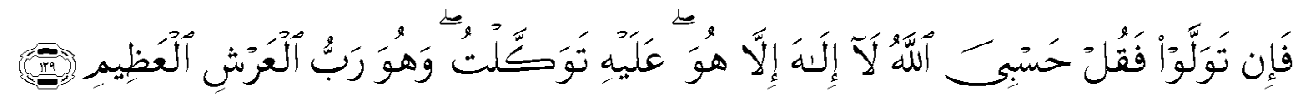

Jika mereka berpaling (dari keimanan), Maka Katakanlab: "Cukuplah Allah bagiKu; tidak ada Tuban selain Dia. Hanya kepada-Nya Aku bertawakkal dan dia adalab Tuban yang memiliki 'Arsy yang agung".

Kedua ayat di atas adalah penutup surah al Taubah. Bila diperhatikan akan terlihat jelas betapa tegas dan keras ayat-ayat surah ini. Basmalah pun tidak diletakkan di awalnya. Sekian banyak beban berat dan kesulitan telah dialami kaum muslimin untuk keluar dari aniaya dan ketidakadilan yang dilakukan oleh kaum kafir dalam rangka meninggikan kalimat Allah. Semua itu dilakukan dengan usaha perjuangan atau jihad melalui peperangan. Pernyataan tentang berlepas dirinya Allah dan Rasul dari para pembangkang (kaum munafik dan kafir yang selalu melanggar perjanjian) merupakan awal uraiannya. Awal surah ini menyatakan keberlepasan Allah dan Rasul-Nya dari kaum musyrikin serta perintah untuk menindak mereka dengan tegas, sedang akhirnya menyatakan kebersamaan dan perlindungan Allah dengan Rasul, dan orangorang beriman.

Ditutupnya ayat di atas dengan pernyataan bahwa Dia adalah pemilik A'rsy yang agung bertujuan untuk mengingatkan kepada kaum muslimin agar mengandalkan Allah semata (tawakal), setelah segala usaha dilakukan (ikhtiar) yang tentunya diawali juga dengan sikap tawakal dengan doa, karena Dia-lah penyebab dari segala sebab dan faktor. Sebab dan faktor selainNya adalah sebab yang tidak sempurna lagi membutuhkan Yang Mahakuasa. ${ }^{46}$

Hal di atas menunjukkan bahwa manusia tidak memiliki kemampuan mendatangkan manfaat dan tidak pula mempunyai kekuatan untuk menampik mudarat kecuali berkat bantuan Allah. Hal ini kemudian akan mengantar kaum muslimin berserah diri kepada Allah, berpegang teguh pada tali agama-Nya yang pada gilirannya mengantar kepada persatuan dan kemenangan. Dengan demikian, dapat dinyatakan bahwa setiap tindakan hendaknya diawali dengan sikap

${ }^{45}$ Syekh Muhammad al Ghazali, A Thematic Commentary on the Qur'an, Translated from the Arabic: Ashur A. Shamis, (Kuala Lumpur: Islamic Book Trust, 2001), h. 196

${ }^{46}$ M. Quraish Shihab, 2010, Ibid, h. 305 
tawakal, yakni berdoa memohon pertolongan kepada Allah agar mendapat kemudahan dalam meraih apa yang diinginkan, lalu dilanjutkan dengan segenap usaha untuk mewujudkannya, dan diakhiri dengan sikap tawakal dengan berserah diri, rela, dan rida dengan segala keputusan Allah, sehingga akan diyakini bahwa keputusan tersebut merupakan pilihan terbaik dari Allah kepadanya.

\section{Penutup}

Islam datang kepada manusia dengan membawa nilai-nilai kebaikan dan menganjurkan manusia agar menghiasi diri dengannya, serta memerintahkan manusia agar memperjuangkannya hingga mengalahkan kebatilan. Namun, hal tersebut tidak dapat terlaksana dengan sendirinya kecuali melalui perjuangan.

Perjuangan atau jihad jika dilihat dari pengertiannya adalah perjuangan dengan motif dan tujuan keagamaan. Oleh karena itu, manifestasi jihad tidak hanya terbatas pada peperangan saja, melainkan dapat dimanifestasikan melalui beragam aktivitas dengan syarat ikhlas dan ditujukan untuk meninggikan kalimat Allah dan mencapai rida-Nya.

Pada masa Rasul seperti yang digambarkan dalam surah al Anfâl dan al Taubah perjuangan atau jihad yang dilakukan Nabi untuk meninggikan kalimat Allah dan membebaskan kaum muslimin dari penindasan kaum musyrikin Mekkah di antaranya banyak dilakukan melalui dakwah dan perang. Di samping itu, dalam pendeskripsian jihad tersebut terdapat pula simpulsimpul pendidikan yang dapat diambil dari surah al Anfâl dan al Taubah seperti yang telah diuraikan di atas.

Pada masa kemerdekaan seperti sekarang perwujudan jihad dapat dilakukan melalui beragam cara. Dengan demikian, memberantas kebodohan, kemiskinan, penyakit jiwa dan raga adalah jihad yang tidak kalah pentingnya dari berperang. Ilmuwan berjihad dengan memanfaatkan ilmunya, karyawan bekerja dengan karyanya yang terbaik, guru dengan pendidikannya yang sempurna, pemimpin dengan keadilannya, pengusaha dengan kejujurannya, dan seterusnya. Dengan memahami perjuangan kaum muslimin pada surah al Anfâl dan al Taubah diharapkan perjuangan atau jihad dapat menciptakan terpeliharanya jiwa dan terwujudnya kemanusiaan yang adil dan beradab.

\section{DAFTAR PUSTAKA}

Abuddin Nata, 2010, Tafsir Ayat-ayat Pendidikan: Tafsir al Ayat al Tarbawy, Jakarta: PT RajaGrafindo Persada.

Ahmadi Sofyan, 2006, Islam on Jihad, Jakarta: Lintas Pustaka.

Al Imam Abu al Fida Ismail Ibnu Kasir al Dimasyqi, 2005, Tafsir Ibnu Katsir, Juz 9, Bandung: Sinar baru Algensindo.

Al Imam Muhammad bin abdul Wahhab, 2008, Mukhtashar Zaadul Ma'ad: Ibnu Qoyyim al-Jaũiyah, Alih Bahasa: Marsuni as-Sasaky, Jakarta: Akbar Media.

Ali Abd al Halim mahmud, 1996, al Tarbiyah al Islamiyah fi surah al Anfâl, Cairo: Daar al Tauzi' wa al Nasyr al Islamiyah.

— , 1998, al Tarbiyah al Islamiyah fi surah al Taubah, Cairo: Daar al Tauzi' wa al Nasyr al Islamiyah. 
Djohan Effendi, 2012, Pesan-pesan al Qur'an, Jakarta: PT Serambi Ilmu Semesta.

M. Dawam Rahardjo, 1996, Ensiklopedi al Qur'an: Tafsir Sosial Berdasarkan Konsep-konsep Kunci, Jakarta: Paramadina.

M. Quraish Shihab, 1997, Wawasan al Qur'an: Tafsir Maudhu'i atas Pelbagai Persoalan Umat, Bandung: Mizan.

—_, 2010, Tafsir al Misbah: Pesan, Kesan, dan Keserasian al Qur'an, Volume 4, Jakarta: Lentera Hati

—, 2010, Tafsir al Misbah: Pesan, Kesan, dan Keserasian al Qur'an, Volume 5, Jakarta: Lentera Hati.

Mahyuddin Barni, 2011, Pendidikan dalam Perspektif al Qur'an: Studi Ayat-ayat al Qur'an tentang Pendidikan, Yogyakarta: Pustaka Prisma

Maktabah Syamilah, Tafsir al Thabari, bab 2, juz 13.

- Tafsir Ibnu Katsir, juz 9.

- Kitab Musnad Ahmad.

$\longrightarrow$, Kitab Shahih Bukhari.

- Kitab Sunan Abu Daud.

Muhammad al Muallim, 1995, Nahwu Tafsir al Maudhu'I Li Suwar al Qur;an al Karim, Cairo: Daar al Syuruf.

Sayyid Quthub, Tafsir Fizhilalil Qur'an (Di bawah Naungan al Qur'an) Jilid 5, 2003, alih bahasa: As'ad Yasin dkk, Jakarta: Gema Insani.

Syekh Muhammad al Ghazali, 2001, A Thematic Commentary on the Qur'an, Translated from the Arabic: Ashur A. Shamis, Kuala Lumpur: Islamic Book Trust.

Wahbah Zuhaili, dkk, 2009, Buku Pintar al Qur'an Seven in One, Jakarta: al Mahira.

Yusuf al Qardhawy, 1980, Pendidikan Islam dan madrasah Hasan al Banna, alih bahasa: Bustami A Gani \& Zainal Abidin Ahmad, Jakarta: Bulan Bintang. 2000, Fatwa-fatwa Mutakhir, alih bahasa: H.M.H. al Hamid al Husaini, Bandung: Pustaka Hidayah. 